\title{
Biochemical Characterization and Nutritional Profile of Jam and Syrup from Saba senegalensis fruit in Côte d'Ivoire
}

\author{
Hadja M. F. Diabagate ${ }^{1}$, Souleymane Traore ${ }^{1}$, Doudjo Soro $^{3}$, Mohamed Cisse $^{2} \&$ Kouakou Brou ${ }^{1}$ \\ ${ }^{1}$ Food Sciences and Technology Department, Laboratory of Nutrition and Food Safety, Nangui Abrogoua \\ University, Abidjan, Côte d'Ivoire \\ ${ }^{2}$ Department of Genetic Biochemistry, Peleforo Gon Coulibaly University, Korhogo, Côte d'Ivoire \\ ${ }^{3}$ Laboratory of Chemical, Food and Environmental Processes Sciences, INP-HB, Yamoussokro, Côte d'Ivoire \\ Correspondence: Hadja Mawa Fatim Diabagaté, Food Sciences and Technology Department, Laboratory of \\ Nutrition and Food Safety, Nangui Abrogoua University, Abidjan, Côte d'Ivoire. Tel: 225-0632-4164. E-mail: \\ fatidiam@yahoo.com
}

Received: September 3, 2020

Accepted: November 6, $2020 \quad$ Online Published: November 25, 2020

doi:10.5539/jfr.v9n6p67

URL: https://doi.org/10.5539/jfr.v9n6p67

\begin{abstract}
Saba senegalensis is a plant to the family of Apocynaceae and its fruit called Saba is mainly used as food. For better valorisation, this study aimed to evaluate the nutritional potential of jam and syrup derived of this fruit. The study was carried out on the fruit of Saba senegalensis harvested in the north of Côte d'Ivoire. After jam and syrup formulation, $\mathrm{pH}$, dry matter, ash, macronutrients, vitamins, minerals, phytonutrients, anti-nutritionals factors and nutritional profile have been determined. The results showed that jam and syrup of Saba were acidic with respective $\mathrm{pH}$ of $3.11 \pm 0.01$ and $3.65 \pm 0.05$. They contented higher in carbohydrates with respective rates of $56.53 \pm 0.24 \%$ and $66.27 \pm 1.08 \%$. Vitamin $C$ rate in jam and syrup was respectively about $20.01 \pm 0.01$ $\mathrm{mg} / 100 \mathrm{~g}$ and $18.33 \pm 2.22 \mathrm{mg} / 100 \mathrm{~g}$. The most important mineral was potassium which rate is $136.71 \pm 4.08$ $\mathrm{mg} / 100 \mathrm{~g}$ and $241.76 \pm 5.9 \mathrm{mg} / 100 \mathrm{~g}$ in jam and syrup respectively. They also contain phytonutrients such as polyphenols (respectively $103.18 \pm 0.69 \mathrm{mg} / 100 \mathrm{~g}$ and $3.29 \pm 0.02 \mathrm{mg} / 100 \mathrm{~g}$ ) and antinutritional factors such as oxalates (respectively $102.01 \pm 6.93 \mathrm{mg} / 100 \mathrm{~g}$ and $19.96 \pm 0.01 \mathrm{mg} / 100 \mathrm{~g}$ ). Nutritional profile has classified Saba Senegalensis jam and syrup to the group 4 of foods, foods that must be eaten occasionally. The transformation of Saba in jam and syrup could be a good way to valorise this fruit and also ensuring its consumption through the year.
\end{abstract}

Keywords: jam, syrup, nutritional profile, nutritional value, Saba senegalensis

\section{Introduction}

Fruits are essential for the alimentation. They have high nutritional value and serve to supplement the nutrients provided by cereals, starchy foods, vegetables (Ojure \& Quadri, 2012). Fruits have generally low content of lipids, sodium, calories and are an important source of many important nutrients such as dietary fibber, vitamin $\mathrm{C}$, minerals and phytonutrients such as phenols and flavonoids. These compounds protect the body against oxidative stress and degenerative diseases by developing the body's ability to defend against external attacks (Yoshikawa, Toyokuni, Yamamoto \& Naito, 2000; Ena, Shalini, Pragati, Reena, \& Rai, 2016). However, the fruits have higher water content, which makes them susceptible to biological and chemical degradation agents such as microorganisms and oxidation reactions (Nout, Hounhouigan, \& Boekel, 2008). The fruits are therefore very perishable and can only be kept fresh for a few days at room temperature, hence the need to transform them. It is in this context that our work is based on the fruit Saba senegalensis better known under the name of côcôta in Côte d'Ivoire, Wèda in Burkina Faso, Madd in Senegal or Saba in French.

Saba senegalensis is a wild liana which pushes in African savannahs (Diabagaté, Traoré, Cissé, Soro, \& Brou 2019). The effects of Saba senegalensis in local traditional medicine are varied. From fruit, to roots, to leaves and latex, everything is usable (Burkill, 2000; Bandoma, 2009; Dari 2013; Sarr et al., 2018). According to Sarr et al. (2015), the crushed leaves of Saba are used for the care of wounds and the roots against female sterility. According to Bâ, Dalpé, and Guissou (1996), the latex of Saba senegalensis combats cough and tuberculosis. In addition, its coagulation gives a natural rubber for various local uses. Nutritionally, the pulp of fruit of Saba 
senegalensis is a true source of $\beta$-carotene $(189.62 \pm 1.33 \mu \mathrm{g} / 100 \mathrm{~g})$ which would play a significant role in the prevention of cancer (Diabagaté et al., 2019). These authors also showed that the pulp was acidic ( $\mathrm{pH}=3.03 \pm$ $0.01)$ and rich in total phenolic $(264.76 \pm 4.54 \mathrm{~g} / 100 \mathrm{~g})$, vitamin $\mathrm{C}(36.67 \pm 2.22 \mathrm{~g} / 100 \mathrm{~g})$, and minerals like potassium $(116.96 \pm 2.06 \mathrm{mg} / 100 \mathrm{~g})$ and calcium $(36.61 \pm 2.79 \mathrm{mg} / 100 \mathrm{~g})$. Moreover, according to Attah et al. (2012) and James, Rotimi, and Bamaiyi (2015), the indigenous fruits are appropriate to be transform into products like juice, jam, syrup and wine that could ameliorate not only the nutrition and health of population, but also livelihoods. Indeed, the processing of these fruits could improve the financial incomes of poor families.

The fruit of Saba senegalensis is a seasonal fruit and therefore not always available. The necessity to transform this fruit into jam and syrup could be one of the ways to valorise the fruit of Saba senegalensis, improve the acceptability of this astringent fruit and ensure its consumption through the year in Côte d'Ivoire. The aim of this study was to determine the nutritional potential of jam and syrup of Saba senegalensis for better valorisation in Côte d'Ivoire.

\section{Material and Methods}

\subsection{Material}

The plant material used in this study is the fruit of Saba senegalensis harvested in the village of Waraniéne located about $5 \mathrm{~km}$ from the city of Korhogo. Waraniéné is located at the North of the Côte d'Ivoire between the parallels $8^{\circ} 26$ and $10^{\circ} 27$ of Northern latitude and $5^{\circ} 17$ and $6^{\circ} 19$ of longitude Western. The ripe fruits of Saba Senegalensis were harvested between May and July 2019 from lianas in the region of Korhogo. The fruits were identified and monitored until the maximum maturity stage. About 10 and 15 healthy orange-yellow fruits were harvested at randomly from each tree.

\subsection{Methods}

\subsubsection{Jam Preparation}

The extraction of raw pulp of Saba was carried out according to the method of Diabagaté $\boldsymbol{e t}$ al. (2019). The Saba Senegalensis fruits $(10 \mathrm{kgs})$ were cutted into half. The pulp with seeds was removed with stainless spoon and were put into the mixer of mark ilux (NO: LX-176P/AC: $220-240 \mathrm{~V} 50 \mathrm{~Hz} 350 \mathrm{~W}$ ) for mixing. The mixture was put into the stainless-steel sieve and blended manually to separate the seeds from the pulp. The pulp obtained was stored at $-20^{\circ} \mathrm{C}$ for analysis. About $500 \mathrm{~g}$ of raw pulp of Saba Senegalensis were mixed with $400 \mathrm{~g}$ of white sugar. The whole was brought to cooking until thickening of the mixture $\left(105^{\circ} \mathrm{C}\right.$ about $\left.20 \mathrm{~min}\right)$. After cooking, the jam was stored in airtight containers.

\subsubsection{Syrup Preparation}

The seeds covered of pulp were soaked for 1 hour in water then kneaded and sieved. The sugar $(750 \mathrm{~g})$ was added to $500 \mathrm{ml}$ of the juice. The mixture was boiled approximately for $10 \mathrm{~min}$ until the sugar was completely dissolved. After cooling, the mixture was stored in airtight containers.

\subsubsection{Chemical Composition of Products Derived from Saba}

\section{pH measurement}

The $\mathrm{pH}$ was determined according to Le Coque (1955) method. It was carried out on the filtrate obtained by grinding $2 \mathrm{~g}$ of sample with $28 \mathrm{ml}$ of distilled water and centrifuged at $3000 \mathrm{rpm}$ for $10 \mathrm{~min}$. The $\mathrm{pH}$ is determined using a $\mathrm{pH}$ meter (Consort $\mathrm{pH}$ meter $\mathrm{P}$ 107).

\section{Titratable acidity}

Titratable acidity was determined according to Kimaryo, Massawi, Olasupo, and Holzapfel (2000) method. Sample ( $2 \mathrm{~g}$ ) was mixed in distilled water $(28 \mathrm{ml})$ and centrifuged at $3000 \mathrm{rpm}$ for $10 \mathrm{~min}$. The filtrate $(10 \mathrm{ml})$ was dosed with a $0.1 \mathrm{~N}$ sodium hydroxide $(\mathrm{NaOH})$ solution and 2 to 3 drops of phenophthalein $(\varphi \varphi)$ were added until it turns pink.

\section{Dry matter content}

Dry matter was determined according to the method of Association of Official Analytical Chemists (AOAC) (1990). The sample was dried with the drying oven (Memmert 854 Schwabach) during $24 \mathrm{~h}$, to $105{ }^{\circ} \mathrm{C}$ and was cooled in a desiccator during $1 \mathrm{~h}$, then weighed and the dry matter was determined.

\section{Ash content}

Ash content was obtained according to AOAC (1990) method. Each jam and syrup (about $5 \mathrm{~g}$ ) was introduced into porcelain capsules and placed in a muffle furnace (JP Sélecta SA 313066) for electric heating for $6 \mathrm{~h}$ at $550^{\circ}$ 
C. After heating, the samples was cooled in a desiccator for $2 \mathrm{~h}$ and the ash were expressed as a percentage of the initial weight of the samples.

\section{Total carbohydrate content}

Total carbohydrate content was determined by difference method:

$$
[100 \%-(\% \text { moisture }+\% \text { ash }+\% \text { fat }+ \text { protein } \%)]
$$

\section{Determination of total sugars}

The total sugars were determined according to the method of Dubois, Gilles, Hamilthon, Rebers, and Smith (1956). One hundred (100) $\mu \mathrm{l}$ of the juice extract were placed in a test tube. Two hundred (200) $\mu 1$ of phenol (5\%, $\mathrm{w} / \mathrm{v}$ ) and one (1) $\mathrm{ml}$ of concentrated sulfuric acid were added successively to the reaction medium. After homogenization of the reaction medium, the optical density is determined using a spectrophotometer (GENESYS 5) at $490 \mathrm{~nm}$ against a control containing no sweet extract. Optical densities were converted into the amount of total sugars using a calibration line obtained from a glucose solution $(1 \mathrm{mg} / \mathrm{ml})$.

$$
\% \text { total sugar }=\mathrm{D} 0490 / \mathrm{a}
$$

a: director coefficient of the calibration line $=9.525$

\section{Determination of reducing sugars}

Reducing sugars were determined by the method of Bernfeld (1955) using dinitrosalicylic acid (DNS). In this method, pentose and hexose, under the effect of heat, transform into furfural compounds. These compounds, in the presence of DNS, produce a specific staining with reducing sugars. The reaction medium was composed of:

- $0.1 \mathrm{ml}$ of sugar extract solution;

- $0.9 \mathrm{ml}$ of distilled water;

$-0.5 \mathrm{ml}$ of DNS.

The mixture was heated in a boiling water bath for $5 \mathrm{~min}$, then allowed to cool for $10 \mathrm{~min}$ at room temperature. Then, $3.5 \mathrm{ml}$ of distilled water are added to the reaction medium. The optical density is read at $540 \mathrm{~nm}$ in the presence of a control. This value is converted into $\mathrm{mg}$ of reducing sugars using a calibration curve obtained from a solution of glucose at $1 \mathrm{mg} / \mathrm{ml}$.

$$
\% \text { reducing sugars }=\text { Do540 } / \mathrm{a}
$$

a: director coefficient of the calibration line $=10.056$

\section{Quantitative determination of Vitamin C}

The method used for the determination of vitamin C was described by Pelletier (1985). The samples (10g) (ME) were diluted in $40 \mathrm{ml}$ of metaphosphoric acid-acetic acid ( $2 \%$; w / v). The mixture was centrifuged at $3000 \mathrm{rpm}$ for 20 minutes and the supernatant was made up to $50 \mathrm{ml}$ with boiled distilled water. A $10 \mathrm{ml}$ sample placed in a vial was titrated with 2.6 DCPIP at $0.5 \mathrm{~g} / \mathrm{L}$ until a persistent pink color was obtained for $30 \mathrm{~s}$. The vitamin C content was given as a percentage according to the following expression:

$$
\text { Vitamine } C(\%)=\frac{\left(0,5 \times \mathrm{V} \times 10^{-3}\right) \times 5}{M E} \times 100
$$

\section{Beta-carotene Content}

Total carotenoids were extracted according to Rodriguez-Amaya (1999) method. Samples were crushed and homogenized. About $5 \mathrm{~g}$ of sample was homogenized with $100 \mathrm{ml}$ of methanol: petroleum ether (1: $9, \mathrm{v} / \mathrm{v})$, the mixture was transferred to a separatory funnel. The petroleum ether layer was filtered through sodium sulfate, transferred to a volumetric flask to a volume of $100 \mathrm{ml}$, made up with petroleum ether. Finally, the total carotenoid content was measured by a spectrophotometer at the wavelength of $450 \mathrm{~nm}$.

The results were expressed in $\beta$-carotene equivalents ( $\mu \mathrm{g} / 100 \mathrm{~g}$ of fresh material).

\section{Fat content}

The fat was extracted according to the method of AOAC (1995). Five grams (5 g) of sample was added to a Whatman cartridge and the whole placed in the extractor of soxhlet. The fat was extracted with $60 \mathrm{ml}$ of hexane at reflux for 6 hours at the boil. The hexane was evaporated using a rotary evaporator. The previously tared extraction flask was dried in an oven at $60^{\circ} \mathrm{C}$. for $30 \mathrm{~min}$ and was cooled in desiccator. The fat content was 
expressed as a percentage of the initial weight of the sample.

\section{Fibbers Content}

Crude fibbers were determined according to AOAC (1990). In $2 \mathrm{~g}$ of sample, were added $50 \mathrm{ml}$ of $0.25 \mathrm{~N}$ sulfuric acid and the mixture was boiled for $30 \mathrm{~min}$ under reflux. About $50 \mathrm{ml}$ of $0.31 \mathrm{~N}$ sodium were added and the whole brought to the boil for $30 \mathrm{~min}$ under cooling agent. The extract obtained was filtered through Whatman filter paper and the residue washed until complete elimination of the alkalis. The residue obtained was incinerated in an oven at $550^{\circ} \mathrm{C}$ for $3 \mathrm{~h}$, cooled in a desiccator and the ash obtained were weighed.

\section{Mineral content}

Ash $(0.1 \mathrm{~g})$ was weighed in platinum crucibles to which was added $1 \mathrm{ml}$ of distilled water. In each crucible, $5 \mathrm{ml}$ of hydrofluoric acid $50 \%$ and 2 drops of sulphuric acid (v/v) were added, homogenized and heated at $100^{\circ} \mathrm{C}$ until fully evaporated. Residue obtained was dissolved in $10 \mathrm{ml}$ of $50 \%$ hydrochloric acid. Solution was left to stand for 10 minutes on the bench and the final volume was brought to $100 \mathrm{ml}$ (Diabagaté et al., 2019). The contents of sodium, magnesium, phosphorus, potassium, calcium and iron were determined by atomic absorption spectrophotometry at their specified wavelengths at $589.3 \mathrm{~nm} ; 285.2 \mathrm{~nm} ; 410 \mathrm{~nm} ; 766.5 \mathrm{~nm} ; 422.7 \mathrm{~nm}$ and 510 $\mathrm{nm}$.

\subsubsection{Phytonutrients}

\section{Polyphenols content}

Total polyphenols content were estimated by the Folin-Ciocalteu method (Scalbert, Monties, \& Janin, 1989). About $200 \mu \mathrm{l}$ of sample were mixed with $800 \mu \mathrm{l}$ of Folin-Ciocalteu reagent. The mixture was kept for 2 minutes in the dark at room temperature and $1 \mathrm{ml}$ of sodium carbonate (75 g.l-1) was added. The mixture was placed in a water bath maintained at $50^{\circ} \mathrm{C}$ for 15 minutes and cooled. The absorbance was measured at $760 \mathrm{~nm}$ using of a UV 1205 spectrophotometer and the results expressed in $\mathrm{mg} / 100 \mathrm{~g}$.

\section{Flavonoids content}

The flavonoid content was determined according to Meda, Lamien, Romito, Millogo and Nacoulma (2005). In a flask contening $0.5 \mathrm{ml}$ of sample, were successively added $0.5 \mathrm{ml}$ of $10 \%$ aluminum chloride, $0.5 \mathrm{ml}$ of $1 \mathrm{~N}$ potassium acetate and $2 \mathrm{ml}$ of distilled water. The mixture was left for 20 minutes in the dark. Optical density was read at $415 \mathrm{~nm}$ against a reference.

\subsubsection{Antinutritionals Factors}

\section{Tannin content}

The tannin content was determined by the method described by Bainbridge, Tomlins, Wellings, and Westby (1996). One $1 \mathrm{ml}$ of sample was added $5 \mathrm{ml}$ of vanillin reagent. The mixture was left for $20 \mathrm{~min}$ in the dark and the optical density (OD) was read at $500 \mathrm{~nm}$ against a blank. The amount of tannins was determined using a standard range established from a stock solution of tannic acid $(2 \mathrm{mg} / \mathrm{ml})$ under the same conditions as the test.

$$
\text { Tannins }(\mathrm{mg} / 100)=\frac{\text { D0500 } \times 103}{3,11 \times \mathrm{me}}
$$

Calibration line: OD500 $=3.11$ mass (mg) Tannic acid

me: mass (g) of the sample.

\section{Phytate content}

The phytate content was determined by the method described by Mohammed, Ponnamperuma, and Youssep (1986). About $0.5 \mathrm{~g}$ of the sample was homogenized in $25 \mathrm{~mL}$ of $3 \%(\mathrm{w} / \mathrm{v})$ trichloroacetic acid (TCA). The mixture was centrifuged at $3500 \mathrm{rpm}$ for $15 \mathrm{~min}$. The supernatant was mixed with $3 \mathrm{~mL}$ of $1 \%$ (w/v) ferric chloride. The solution obtained was heated in boiling water bath for $45 \mathrm{~min}$. After cooling, the solution was centrifuged at $3500 \mathrm{rpm}$ for $10 \mathrm{~min}$. The supernatant was mixed with $5 \mathrm{~mL}$ of hydrochloric acid $(0.5 \mathrm{~N})$. To the mixture obtained, $5 \mathrm{ml}$ of sodium hydroxide $(1.5 \mathrm{~N})$ were added and the whole was taken to a boiling water bath for $15 \mathrm{~min}$. The solution obtained was centrifuged at $3500 \mathrm{rpm}$ for $10 \mathrm{~min}$. To the supernatant $(1 \mathrm{~mL}), 4.5 \mathrm{~mL}$ of boiled, air-cooled distilled water and $4.5 \mathrm{~mL}$ of orthophenantroline reagent were added. The mixture was left for 1 hour before reading the optical density (OD) at $470 \mathrm{~nm}$ against a blank. A standard range was established from a stock solution of Mohr's salt $(10 \mu \mathrm{g}$ iron $/ \mathrm{mL})$ under the same conditions as the test for the determination of the amount of phytate-ferric in the sample. 


$$
\text { Phytates }(\mathrm{mg} / 100)=\frac{\mathrm{DO}_{470} \times 4}{0,033 \times \mathrm{m}_{\mathrm{e}}}
$$

Calibration line: OD $(470)=0.033$ mass $(\mu \mathrm{g})$ Phytate sodium

me: mass $(\mathrm{g})$ of the sample.

\section{Oxalic acid}

The oxalic acid (OA) content was determined according to the method described by AOAC (1995). About $0.5 \mathrm{ml}$ of sample was added to $100 \mathrm{ml}$ of potassium hydroxide $(0.1 \mathrm{~N} \mathrm{KOH})$. The mixture was boiled for $30 \mathrm{~min}$ at $80^{\circ} \mathrm{C}$. After cooling, the solution was filtered and $5 \mathrm{ml}$ of concentrated sulfuric acid (H2SO4) was added. The filtrate is heated ta the temperatures at $60^{\circ} \mathrm{C}$ to $70^{\circ} \mathrm{C}$ for $10 \mathrm{~min}$ then titrated with $0.1 \mathrm{~N}$ potassium permanganate solution (KMnO4) until a persistent pink color. The content of oxalic acid was determined by the following relationship:

$$
\% \mathrm{OA}=\frac{\mathrm{V} \times 0,45 \times 2}{\mathrm{Pe}}
$$

Pe: The test sample $(0.5 \mathrm{~g})$

$\mathrm{V}$ : burette drop (KMnO4) or volume of $\mathrm{KMnO} 4$ poured

0.45 = quantity of oxalic acid corresponding to 1 liter of $0.1 \mathrm{~N}$ solution of $\mathrm{KMnO} 4$

\subsubsection{Nutritional Profile}

Food nutrient profile was calculated according to Darmon, Vieux, Maillot, Volatier, and Martin (2009) system. This system is based on two (2) indicators: the SAIN score, based on qualifying nutrients (ie, positive nutrients), and the LIM score, based on disqualifying nutrients (ie, the nutrient to be limited).

The SAIN score was an unweighted arithmetic mean of the percentage adequacy for Five (5) positive nutrients. It was calculated for $100 \mathrm{kcal}$ of food, as follows:

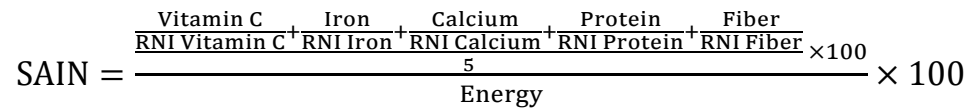

RNI (Recommended Nutritional Intake)

The LIM score was the mean percentage of the maximal recommended values for 3 nutrients, the intakes of which should be limited in a healthy diet.

The LIM score was calculated for $100 \mathrm{~g}$ of food as follows:

$$
\operatorname{LIM}=\frac{\frac{\mathrm{Na}}{3153}+\frac{\mathrm{SFA}}{22}+\frac{\text { Added sugar }}{50}}{3} \times 100
$$

\section{SFA $=$ Saturated Fatty Acid}

The recommended nutritional intake are based on French and European nutritional recommendations. In particular, the daily maximal recommended value for SFAs and added sugars corresponded to $10 \%$ of $2000 \mathrm{kcal}$, ie, 22 and $50 \mathrm{~g}$, respectively, and that of sodium corresponded to a daily intake of $8 \mathrm{~g} \mathrm{NaCl}$ (ie, $3153 \mathrm{mg} \mathrm{Na}$ ). The 2000-kcal value was chosen as a reference for energy intake because it is close to the mean observed energy intakes in the French population. Overall, the SAIN, LIM system was based on 8 basic nutrients (5 included in the SAIN plus 3 included in the LIM) (Darmon et al., 2009).

Based on reference daily energy intake of $2000 \mathrm{kcal}$, the optimum value for the SAIN was $100 \%$ for $2000 \mathrm{kcal}$, which was equivalent to $5 \%$ for $100 \mathrm{kcal}$ food. The SAIN value $\geq 5$ indicated, therefore, a good nutrient density. Unlike the SAIN, the LIM was calculated for $100 \mathrm{~g}$. Thus, the reference value used to derive the threshold value for the LIM score was based on food intake rather than on energy intake. Because the mean daily food intake (including solid foods only) observed in the French population was $\approx 1330 \mathrm{~g} / \mathrm{d}$, the maximal value for the LIM score was $100 \%$ for $1330 \mathrm{~g}$, which was equivalent to $7.5 \%$ for $100 \mathrm{~g}$ food. A LIM value <7.5 indicated, therefore, a low content of limited nutrients (Darmon et al., 2009).

Based on SAIN and LIM score values, each food was classified into 1 of 4 possible SAIN and LIM groups (Darmon et al., 2009):

Group 1: SAIN $\geq 5$ and LIM $<7.5$ (Foods recommended for health) 
Group 2: SAIN $<5$ and LIM $<7.5$ (Neutral foods)

Group 3: SAIN $\geq 5$ and LIM $\geq 7.5$ (Foods recommended in small quantities or occasionally)

Group 4: SAIN $<5$ and LIM $\geq 7.5$ (Foods to limit).

\subsubsection{Statistical Analysis}

Results made in triplicate measurements were expressed as means with standard deviation. A one-way ANOVA was performed and means were separated using Tukey test $(\mathrm{p} \leq 0.05)$ with Statistica 7.1 software.

\section{Results}

\subsection{Biochemical Composition of Jam and Saba Syrup}

\subsection{1 pH, Titratable Acidity, Ash and Dry Matter}

The $\mathrm{pH}$, titratable acidity, ash and dry matters contents of jam and syrup of Saba were given in Table 1. Results showed that $\mathrm{pH}$, titratable acidity, ash and dry matters differ significantly to the jam and syrup of Saba. The jam and the syrup have low $\mathrm{pH}$ values (respectively $3.11 \pm 0.01$ and $3.65 \pm 0.05$ ) with a titratable acidity respectively of $0.23 \pm 0.01 \%$ and $0.09 \pm 0.01 \%$. On the other hand, the dry matter contents was higher than $50 \%$. Also, they contained respectively $0.63 \pm 0.05 \%$ and $1.06 \pm 0.09 \%$ of ash.

Table 1 . Compositions in $\mathrm{pH}$, titratable acidity, ash and dry matter

\begin{tabular}{lll}
\hline & Contents \\
\cline { 2 - 3 } & Jam & Syrup \\
\hline pH & $3.11 \pm 0.01^{\mathrm{b}}$ & $3.65 \pm 0.05^{\mathrm{a}}$ \\
Titratable acidity & $0.23 \pm 0.01^{\mathrm{a}} \%$ & $0.09 \pm 0.01^{\mathrm{b}} \%$ \\
Ash & $0.63 \pm 0.05^{\mathrm{b}} \%$ & $1.06 \pm 0.09^{\mathrm{a}} \%$ \\
Dry matters & $58.08 \pm 0.37^{\mathrm{b}} \%$ & $67.47 \pm 1.45^{\mathrm{a}} \%$ \\
\hline
\end{tabular}

Values are means \pm standard deviations of three measures $(n=3)$. The same letter subscripted in the same line indicates that there is no significant difference between samples for the parameter concerned $(p<0.05)$.

\subsubsection{Macronutrient Content}

Macronutrient content were significantly different $(\mathrm{P}<0.05)$ in the jam and the syrup of Saba Senegalensis (Table 2). Results showed that the jam and the syrup had low lipid contents (respectively $0.92 \pm 0.06 \%$ and $0.13 \pm$ $0.01 \%)$. On the other hand, the syrup $(66.27 \pm 1.08 \%)$ was higher total carbohydrate content than the jam $(56.53 \pm 0.24 \%)$. The total sugars contents of the jam and the syrup were respectively $13.36 \pm 0.14 \%$ and 17.35 $\pm 0.30 \%$.

Table 2. Macronutrient compositions of Jam and Saba Syrup

\begin{tabular}{lll}
\hline & \multicolumn{2}{l}{ Contents (\%) } \\
\cline { 2 - 3 } & Jam & Syrup \\
\hline Lipids & $0.92 \pm 0.06^{\mathrm{a}}$ & $0.13 \pm 0.01^{\mathrm{b}}$ \\
Total carbohydrates & $56.53 \pm 0.24^{\mathrm{b}}$ & $66.27 \pm 1.08^{\mathrm{a}}$ \\
Total sugar & $43.36 \pm 0.14^{\mathrm{b}}$ & $47.35 \pm 0.30^{\mathrm{a}}$ \\
Reducer sugar & $3.05 \pm 0.34^{\mathrm{a}}$ & $0.28 \pm 0.02^{\mathrm{b}}$ \\
\hline
\end{tabular}

Values are means \pm standard deviations of three measures $(n=3)$. The same letter subscripted in the same line indicates that there is no significant difference between samples for the parameter concerned $(p<0.05)$.

\subsubsection{Vitamins and Minerals}

The Table 3 presented the vitamin C, $\beta$-carotene and minerals contents of jam and syrup of Saba senegalensis. Results showed the significant difference between the parameters studied. The vitamin $C$ rate was highest in the jam $(20.00 \pm 0.01 \mathrm{mg} / 100 \mathrm{~g})$ that in the syrup $(18.33 \pm 2.22 \mathrm{mg} / 100 \mathrm{~g})$. In addition, $\beta$-carotene rate of the jam was $174.34 \pm 3.01 \mu \mathrm{g} / 100 \mathrm{~g}$ while its content in the syrup was in the traces form.

Concerning minerals contents, potassium was the most abundant mineral in jam and syrup with respective values of $136.71 \pm 4.08 \mathrm{mg} / 100 \mathrm{~g}$ and $241.76 \pm 5.9 \mathrm{mg} / 100 \mathrm{~g}$. The formulated products contained a significant amount of calcium $(53.46 \pm 3.96 \mathrm{mg} / 100 \mathrm{~g}$ and $87.49 \pm 5.42 \mathrm{mg} / 100 \mathrm{~g})$. Nevertheless, they were low in iron contents $(1.01 \pm 0.21 \mathrm{mg} / 100 \mathrm{~g}$ and $3.11 \pm 0.87 \mathrm{mg} / 100 \mathrm{~g})$. 
Table 3. Vitamins and minerals contents

\begin{tabular}{lll}
\hline & Contents & \\
\cline { 2 - 3 } & Jam & Syrup \\
\hline Vitamins & & \\
Vitamin C & $20.00 \pm 0.01^{\mathrm{a}} \mathrm{mg} / 100 \mathrm{~g}$ & $18.33 \pm 2.22^{\mathrm{b}} \mathrm{mg} / 100 \mathrm{~g}$ \\
$\beta$-carotene & $174.34 \pm 3.01^{\mathrm{a}} \mu \mathrm{g} / 100 \mathrm{~g}$ & Traces \\
Minerals & Jam $\left(\mathbf{m g} / \mathbf{1 0 0}^{\mathrm{g}}\right)$ & Syrup $(\mathbf{m g} / \mathbf{1 0 0} \mathbf{g})$ \\
Sodium $(\mathrm{Na})$ & $5.25 \pm 0.31^{\mathrm{b}}$ & $18.80 \pm 1.08^{\mathrm{a}}$ \\
Magnesium $(\mathrm{Mg})$ & $16.19 \pm 0.21^{\mathrm{b}}$ & $34.49 \pm 0.54^{\mathrm{a}}$ \\
Phosphorus (P) & $14.19 \pm 0.44^{\mathrm{b}}$ & $40.46 \pm 1.32^{\mathrm{a}}$ \\
Potassium (K) & $136.1 \pm 4.08^{\mathrm{b}}$ & $241.76 \pm 5.90^{\mathrm{a}}$ \\
Calcium (Ca) & $53.46 \pm 3.96^{\mathrm{b}}$ & $87.49 \pm 5.42^{\mathrm{a}}$ \\
Iron (Fe) & $1.01 \pm 0.21^{\mathrm{b}}$ & $3.11 \pm 0.87^{\mathrm{a}}$ \\
\hline
\end{tabular}

Values are means \pm standard deviations of three measures $(n=3)$. The same letter subscripted in the same line indicates that there is no significant difference between samples for the parameter concerned $(\mathrm{p}<0.05)$.

\subsection{Phytonutrients and Anti-nutritional Factors}

The phytonutrients content and antinutritionals factors content were shown in Table 4. Results were significantly different $(\mathrm{p}<0.05)$ on phytonutrients and anti-nutritional factors in each formulated products. Polyphenols were more abundant in Saba Senegalensis jam $(103.18 \pm 0.69 \mathrm{mg} / 100 \mathrm{~g})$ than in syrup $(3.29 \pm 0.02 \mathrm{mg} / 100 \mathrm{~g})$. In addition, phytates were more abundant in Saba jam $(102 \pm 6.93 \mathrm{mg} / 100 \mathrm{~g})$. Results also showed that flavonoids content were lower in jam and syrup of Saba with respective values of $19.00 \pm 0.99 \mathrm{mg} / 100 \mathrm{~g}$ and $0.20 \pm 0.02$ $\mathrm{mg} / 100 \mathrm{~g}$.

Table 4. Phytonutrients contents and antinutritionals factors

\begin{tabular}{lll}
\hline Contents (mg/100g) & & \\
\hline & Jam & Syrup \\
\hline Phytonutrients & & \\
Total polyphenols & $103.18 \pm 0.69^{\mathrm{a}}$ & $3.29 \pm 0.02^{\mathrm{b}}$ \\
Flavonoids & $19.00 \pm 0.99^{\mathrm{a}}$ & $0.20 \pm 0.02^{\mathrm{b}}$ \\
Antinutritionals Factors & & \\
Tannins & $78.51 \pm 0.14^{\mathrm{a}}$ & $1.08 \pm 0.04^{\mathrm{b}}$ \\
Phytates & $102 \pm 6.93^{\mathrm{a}}$ & $19.96 \pm 0.01^{\mathrm{b}}$ \\
Oxalates & $19.87 \pm 0.01^{\mathrm{a}}$ & $6.62 \pm 0.21^{\mathrm{b}}$ \\
\hline
\end{tabular}

Values are means \pm standard deviations of three measures $(n=3)$. The same letter subscripted in the same line indicates that there is no significant difference between samples for the parameter concerned $(\mathrm{p}<0.05)$.

\subsection{Nutritional Profile}

The Figure 1 showed the SAIN and LIM scores for jam and syrup of Saba Senegalensis. The SAIN score of the jam was 2.88 and LIM score was 54.70. The SAIN score of the syrup was 3.85 and LIM score was 97.39. 


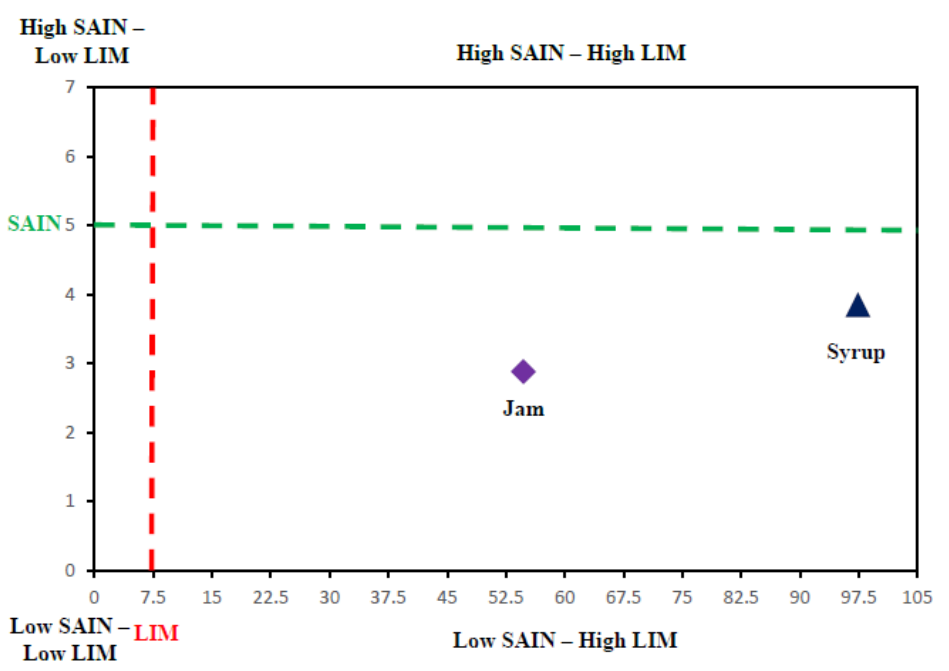

Figure 1. Nutritional profile of jam and syrup of Saba

\section{Discussion}

The aim of this study was to evaluate the nutritional potential of jam and syrup of Saba senegalensis for better valorisation of this fruit. The $\mathrm{pH}$ value showed that jam and syrup was acidic. It was established that acidity is one of the main parameters that determine the quality of food and it is due to the presence of organic acids (Ouchemoukh, Louaileche, \& Schweitzer, 2007). The acid content of the jam and the syrup of Saba Senegalensis obtained in this result indicated that Saba Senegalensis fruit could contain organic acids. Due to the high acidic content, jam and syrup of Saba senegalensis could be able to tolerate microbial activities, especially pathogenic germs and will have a long shelf life. According to Vondruskova, Slamova, Trckova, Zraly, and Pavlik (2010), organic acids have the ability to lower $\mathrm{pH}$ and thereby reduce the growth of certain pathogenic bacteria. The dry matter corresponds to the mass of sample after complete evaporation of the free water. The dry mater content in jam and syrup of Saba Senegalensis was higher than $50 \%$. This property would indicate that the jam and the syrup could resist a long time against the microbial growth. Dry matter contents was higher than those obtained by Badarou and Sanni (2014) in tamarind jam $\approx 54 \pm 1.79 \%$ and pineapple syrup $\approx 21.40 \%$. Carbohydrates content in this result were higher than $50 \%$. The high carbohydrate content in jams can be associated to the large presence of sugar (> $50 \mathrm{~g} / 100 \mathrm{~g}$ ) as observed from the nutrition labelling on its packaging (Whitney \& Rolfes, 2005; Naeem et al., 2017). The total sugars contents $(43.36 \pm 0.14 \%)$ obtained in this result were lower than those of Parkouda, Oboulbiga, and Sawadogo-Lingani (2015) in the Saba jam in Burkina Faso (65.36 $\pm 0.92 \%)$. The difference of sugars obtained in this result and those of Parkouda et al. (2015) could be explained either by the different varieties of the fruit or by the technological treatments applied.

According to Khalil and Saleemullah (2004), carotenoids is the biological antioxidants and play an important role in human health. $\beta$-carotene was converted into retinol (vitamin A) in the human body with a better yield estimated at 1/6 (Favier et al., 1993; Diabagaté et al., 2019). Vitamin A was involved in growth, vision, and resistance to infection and its deficiency is a major contributor to infant and child mortality (Tee, 1992; Diabagaté et al., 2019). Saba Senegalensis jam could thus contribute to the recommended nutritional intake of carotenoids, especially in children. The $\beta$-carotene content of Saba syrup was in the form of traces. The great loss of carotenoids in the syrup could be explained by the method of manufacture of the Saba juice used for the formulation of the syrup and by the cooking method. Indeed, according to Alvarez-Jubete and Tiwari (2013), cooking influences the carotenoid content with varying degrees of stability between the different compounds. Saba Senegalensis jam and Saba Senegalensis syrup have high content of vitamin C. According to the Institute of Medicine (2005) for the consumption of vitamin C, the Accepted Daily Intake (ADI) permitted is $110 \mathrm{mg} /$ days. Due to the high content of vitamin C, the consumption of jam and syrup of Saba could be contribute to attain the requirement daily of vitamin $\mathrm{C}$. In this study, the ash content obtained was higher than that reported by Parkouda et al. (2015) in Saba jam from Burkina Faso, which was $0.35 \pm 0.01 \%$. The difference of ash contents obtained in this result and those of the literature could be explained either by the different varieties, the geographical locations of Saba studied or by the technological treatments applied. The ash contents in food explain that it contain a significant amount of minerals. 
Minerals are extremely important because they are responsible to several metabolic reactions in body (Traoré, Assemand, Digbeu, Kouadio, \& Brou, 2018). This result showed that potassium was abundant in jam and syrup of Saba Senegalensis. As far as potassium, the potassium content of Saba jam was higher than that obtained by Ajenifujah-Solebo and Aina (2011) in plum jam $(90.42+0.01 \mathrm{mg} / 100 \mathrm{~g})$. Moreover, the potassium content of Saba senegalensis syrup $(241.76 \pm 5.90 \mathrm{mg} / 100 \mathrm{~g})$ were higher than those obtained by Agence Nationale de Sécurité Sanitaire, alimentation, Environnement et travail (ANSES) (2013) in pineapple syrup (105 mg/100 g). Potassium is well known for its important role in regulating heart rate and neurotransmission (Alinnor \& Akalezi, 2010. As the importance of these potassium contents, jam and syrup of Saba could be appropriate to help solve the problems of sodium-related diseases. The calcium contents in Saba jam $(53.46 \pm 3.96 \mathrm{mg} / 100 \mathrm{~g})$ and the Saba syrup $(87.49 \pm 5.42 \mathrm{mg} / 100 \mathrm{~g})$ were respectively higher than those of papaya jam $(36.00 \pm 1.00 \mathrm{mg} / 100 \mathrm{~g})$ reported by Ena, Shalini, Pragati, Reena, and Rai, (2016) and date syrup (44.41 mg/100g) reported by Farahnaky, Mardani, Mesbahi, Majzoobi, and Golmakani (2016). The relatively high levels of calcium in the two products suggest that they could have therapeutic value in a hypocalcaemia state such as osteoporosis. Indeed, calcium is a major factor in ossification and plays a role in muscle contraction, and absorption of vitamin B12 (Mensah, Okoli, Ohaju-Obodo, \& Eifediyi 2008). The studies carried out by Onwuliri and Obu (2002) have showed that the minerals were important for their absolute involvement in vital physiological functions such as the regulation of osmotic pressure, regulation of electrolyte flows between the intra-and extracellular medium (by $\mathrm{Na} / \mathrm{K}$ pump) (Traoré et al., 2018). Due to the high potassium content, jam and syrup of Saba senegalensis could be recommended in diet.

As for as the antinutritional factor, results showed the high level of phytates and tannins in jam and syrup of Saba senegalensis. Indeed, the high content of phytates and tannins in diet could be responsible for the unavailability of certain minerals such as iron, Zinc, magnesium and calcium (Traoré et al., 2018). In addition to the antinutritional factor, the jam and syrup of Saba senegalensis contained phytonutrients, which play the role of antioxidants. In previous studies, Weiguang, Joan, and Casimir (2005) demonstrated that polyphenols was considered as powerful antioxidants against radical phenomena leading to tissue or cellular degeneration. Furthermore, Sarni-Manchado and Cheynier (2006) showed that they are able to activate the natural anti-cancer defences. The flavonoid content of Saba jam $(19.00 \pm 0.99 \mathrm{mg} / 100 \mathrm{~g})$ was higher than that of strawberry jam $(14.08 \pm 0.99 \mathrm{mg} / 100 \mathrm{~g})$ reported by Branka, Danijela, Martina, and Dragović-Uzelac (2012). Moreover, the total phenolic content $(103.18 \pm 0.69 \mathrm{mg} / 100 \mathrm{~g})$ of the jam was higher than that obtained by Patras, Brunton, Tiwari, and Butler (2011) for strawberry jam $(83.71 \pm 0.90 \mathrm{mg} / 100 \mathrm{~g})$. The total phenolic and flavonoid contents of jam and syrup of Saba could give those potential therapeutic or preventive properties.

With regard to nutritional profile, results showed that jam and syrup of Saba have low score SAIN (SAIN <5) and high LIM score (LIM> 7.5). The SAIN and LIM scores have classified the jam and syrup of Saba senegalensis belong to the group 4 of foods, foods that must be consumed with moderation and therefore occasionally. For a better consumption of the syrups and jams of Saba senegalensis, it will be interesting to produce them without added sugar. The results were in agreement with those of Darmon et al. (2004) who classified products rich in sugar as foods to limit in consumption. For a better consumption of foods from this group, it will be interesting to produce jams and syrup of Saba senegalensis without added sugar. Contrary to these results, several studies classified cowpea seeds in food of group 1, recommended foods for health because cowpea seeds have high score SAIN higher than 5 and low score LIM lower than 7.5 (Traoré et al., 2018; Traoré et al., 2020).

\section{Conclusion}

The present study showed that jam and syrup of Saba senegalensis were an important source of minerals such as magnesium, potassium, calcium and phosphorus. In addition, jam and syrup of Saba contained high rate of carbohydrates, total sugars, phenolic compounds and vitamin $C$ whose presence facilitates the absorption of minerals. The nutritional profile showed that jam and syrup of Saba belong to the group of foods who must be consumed moderately. For a better consumption, it is desirable to produce jam and syrup of Saba Senegalensis fruit without added sugar. This study has shown that Saba jam and Saba syrup have a high nutritional value and could thus contribute to the improvement of the population's diet and these products would offer interesting possibilities of the economic market.

\section{Statement of competing interests}

The authors have no competing interest in relation to their work.

\section{Acknowledgements}

Authors would like to thank all the farmers for their generosity, technical assistance and documentation. Their 
also thank the Nutrition and Technology teams of the Nangui Abrogoua University, the Peleforo Gon Coulibaly University and the National Polytechnic Institute Houphouet Boigny (INP-HB) for their contribution in this study.

\section{References}

Agence Nationale de sécurité sanitaire, alimentation, Environnement et travail (ANSES). (2013). Table Ciqual, Composition nutritionnelle des aliments. Retrieved from https://pro.anses.fr/tableciqual/index.htm

Ajenifujah-Solebo, S. O., \& Aina, J. O. (2011). Physico-chemical properties and sensory evaluation of jam made from black-plum fruit (Vitex doniana). African Scholarity Science Communications Trust, 11(3), 4772-4784. https://doi.org/10.4314/ajfand.v11i3.66629

Alinnor, I. J., \& Akalezi, C. O. (2010). Proximate and Mineral Compositions of Dioscorea rotundata (White Yam) and Colocasia esculenta (White Cocoyam). Department of Pure and Industrial Chemistry, Federal University of Technology, P.M.B. 1526, Owerri, Imo State, Nigeria. Pakistan Journal of Nutrition, 9(10), 998-10010. http://dx.doi.org/10.3923/pjn.2010.998.1001

Alvarez-Jubete, L., \& Tiwari, U. (2013). Stability of phytochemicals during grain processing. In B. K. Tiwari, N. P. Brunton \& C. S. Brennan (Eds.), Handbook of Plant Food Phytochemicals Sources, Stability and Extraction (pp. 303-333). 1ère edition, John Wiley \& Sons, Ltd. https://doi.org/10.1002/9781118464717.ch14

Association of Official Analytical Chemists (AOAC). (1990). Official Methods of Analysis (15th ed.). Washington D.C. p. 375-379.

Association of Official Analytical Chemists (AOAC). (1995). Official Methods of Analysis (15th ed.). Washington D.C. p. 375-379.

Attah, A. F., O'Brien, M., Koehbach, J., Onibare, M. A., Moody, J. O., \& Smith, T. J. (2012). Uterine contractility of plants used to facilitate childbirth in Nigerian ethnomedicine. Journal of Ethnopharmacology, 143(1), 377-382. https://doi.org/10.1016/j.jep.2012.06.042

Bâ, A. M., Dalpé, Y., \& Guissou, T. (1996). Les Glomales d'Acacia holosericea et d'Acacia mangium: diversité et abondance relative des champignons mycorhiziens à arbuscules dans deux types de sols de plantations au Burkina Faso. Bois et Forêts des Tropiques, 250, 5-18. https://doi.org/10.19182/bft1996.250.a19862

Badarou, G., \& Sanni, N. (2014). Evaluation des propriétés physico chimiques, microbiologiques et sensorielles d'une confiture de tamarin (Tamarindus indica l.) allégée en sucre. Rapport de fin de formation en Licence Professionnelle, Université d'Abomey-Calavi, Abomey, Bénin. p. 48.

Bainbridge, Z., Tomlins, K., Wellings, K., \& Westby, A. (1996). Methods for assessing quality characteristics of non-grains starch staples (Part 3. Laboratory methods). Chatham, UK: Natural Resources Institute, 83, 185-193. Retrieved from http://gala.gre.ac.uk/10986

Bandoma, E. (2009). Fruits characterization of (ORA), (Saba senegalensis) in some parts of the Upper West Region. A Dissertation to the Horticulture department of the University for Development Studies (unpublished). p. 4-7.

Bernfeld, P. (1955). Amylase $\alpha$ and $\beta$. Methods in enzymology Colwich and N.O Kaplan (9th ed.). Academic Press, Inc., New York. p. 154. http://dx.doi.org/10.1016/0076-6879(55)01021-5

Branka, L., Danijela, B. K., Martina, B., \& Dragović-Uzelac, V. (2012). Influence of jam processing upon the contents of phenolics and antioxidant capacity in strawberry fruit (Fragaria ananassa $\times$ Duch.). Croatian journal of food technology, biotechnology and nutrition, 7, 18-22. Retrieved from https://www.researchgate.net/publication/273633104_Influence_of_Jam_Processing_Upon_the_Contents_o f_Phenolics_and_Antioxidant_Capacity_in_Strawberry_fruit_Fragaria_ananassa_Duch

Burkill, H. M. (2000). The useful plants of West Tropical Africa. Families E-I. Royal Botanical Garden, Kew, $U K, 2(5), 636$.

Dari, L. (2013). Nutritional composition and stability of Saba senegalensis fruit extract, Faculty of Agriculture University for Development Studies, Tamale, Ghana. International Conference on Neglected and Underutilized Species: for a Foodsecure Africa, Accra, Ghana. p. 12.

Darmon, N., Briend, A., \& Drewnowski, A. (2004). Energy-dense diets are associated with lower diet costs: A community study of French adults. Public Health Nutrition, 7(1), 21-27.

https://doi.org/10.1079/phn2003512 
Darmon, N., Vieux, F., A., Maillot, M, Volatier, J-L., \& Martin, A. (2009). Nutrient profiles discriminate between foods according to their contribution to nutritionally adequate diets: a validation study using linear programming and the SAIN, LIM system. American Journal of Clinical Nutrition, 89, 1227-36. https://doi.org/10.3945/ajcn.2008.26465

Diabagaté, H. M. F., Traoré, S., Cissé, M., Soro, D., \& Brou, K. (2019). Biochemical characterization and nutritional profile of the pulp of Saba senegalensis from Côte d'Ivoire forest. American Journal of Food and Nutrition, 7(1) 19-25. https://doi.org/10.12691/ajfn-7-1-4

Dubois, M., Gilles, K. A., Hamilthon, J. K., Rebers, P. A., \& Smith F. (1956). Colorimetric method for determination of sugars and related substances. Anal. Chem., 28, 350-356. https://doi.org/10.1021/ac60111a017

Ena, G., Shalini, P., Pragati, J., Reena, C., \& Rai, G. K. (2016). Sensory Evaluation and Nutritional Composition of Developed Papaya-Gooseberry Jam. Food and Nutrition Sciences, 7, 600-608. https://doi.org/10.4236/fns.2016.77061

Farahnaky, A., Mardani, M., Mesbahi, G., Majzoobi, M., \& Golmakani, M. T. (2016). Some physicochemical properties of date syrup, concentrate, and liquid sugar in comparison with sucrose solutions. Journal of Agricultural Science and Technology, 18(3), 657-668. Retrieved from http://jast.modares.ac.ir/article-23-4268-en.html

Favier, J. C., Ireland-Ripert, J., Laussucq, C., \& Feinberq, M. (1993). Répertoire général des aliments T3: table de composition des fruits exotiques, fruits de cueillette d'Afrique. Techniques et documentation. p. 55.

Institute of Medicine (2005). Dietary Reference Intakes for Water, Potassium, Sodium, Chloride and Sulfate. National Academy Press, Washington, DC. p. 617.

James, O., Rotimi, A. A., \& Bamaiyi, B. O. J. (2010). Phytoconstituents, proximate and nutrient investigations of Saba florida (Benth.) from Ibaji forest. International Journal of Nutrition and Metabolism, 2(5), 88-92. Retrieved from http://www.academicjournals.org/ijnam

Khalil, I. A., \& Saleemullah (2004). Book of Bio Analytical Chemistry (2nd ed.). National Book Foundation Islamabad. p. 26-29.

Kimaryo, V.M., Massawi, G.A., Olasupo, N.A. \& Holzapfel, W.H. (2000). The use of a stater culture in the fermentation of cassava for the production of "Kivunde", a traditional Tanzanian food product. International Journal of Food Microbiology 56: 179-190. htpps://doi.org/10.1016/s0168-1605(00)00159-8

Le Coque, R. (1955). Bureau interprofessionnel d'Etudes Analytiques. Recueil de méthodes d'analyses des communautés Européennes.

Meda, A., Lamien, C. E., Romito, M., Millogo, J., \& Nacoulma, O. G. (2005). Determination of the total phenolic, flavonoid and proline contents in Burkina Faso honey, as well as their radical scavenging activity. Food Chemistry, 91, 571-577. https://doi.org/10.1016/j.foodchem.2004.10.006

Mensah, J. K., Okoli, R. I., Ohaju-Obodo, J. O., \& Eifediyi, K. (2008). Phytochemical, nutritional and medical properties of some leafy vegetables consumed by Edo people of Nigeria. Africa Journal of Biotechnologies, 7(14), 2304-2309. Retrieved from http://www.academicjournals.org/AJB

Mohammed, A. I., Ponnamperuma, A. J. P., \& Youssep, S. H. (1986). New chromophore method for phytic acid determination?. Cereal Chemistry, 63(6), 475-478. https://doi.org/10.2466/pms.1986.63.2.475

Naeem, M. N., Fairulnizal, M. M. N., Norhayati, M. K., Zaiton, A., Norliza, A. H., Syuriahti, W. Z. W., Azerulazree, J. M., Aswir, A. R., \& Rusidah, S. (2017). The nutritional composition of fruit jams in the Malaysian market. Journal of the Saudi Society of Agricultural Sciences, 16, 89-96. http://dx.doi.org/10.1016/j.jssas.2015.03.002

Nout, R., Hounhouigan, J. D., \& Boekel, V. T. (2008). Les aliments transformation, conservation et qualité. p. 90-231.

Ojure, M. A., \& Quadri, J. A. (2012). Quality evaluation of noodles produced from unripe plantain flour using xanthan gum. International Journal of Recent Research and Applied Studies, 13(3), 740-752. Retrieved from http://www.arpapress.com/Volumes/Vol13Issue3/IJRRAS_13_3_09.pdf

Onwuliri, V. A., \& Obu, J. A. (2002). Lipids and other constituents of Vigna unguiculata and Phaseolus vulgaris grown in northern Nigeria. Food Chemistry, 78, 1-7. https://doi.org/10.1016/S0308-8146(00)00293-4 
Ouchemoukh, S., Louaileche, H., \& Schweitzer, P. (2007). Physicochemical characteristics and pollen spectrum of some Algerian honeys. Food Control, 18, 52-58. https://doi.org/10.1016/j.foodcont.2005.08.007

Parkouda, C., Oboulbiga, B. E., \& Sawadogo-Lingani, H. (2015). Fabrication de confiture de liane goïne (Saba senegalensis). Retrieved from

https://www.researchgate.net/publication/322745793_Fabrication_de_confiture_de_liane_goine_Saba_sene galensis

Patras, A., Brunton, N. P., Tiwari, B. K., \& Butler, F. (2011). Stability and Degradation Kinetics of Bioactive Compounds and Colour in Strawberry Jam during Storage. Food Bioprocess Technology, 4(7), 1245-1252. https://doi.org/10.1007/s11947-009-0226-7

Pelletier, O. (1968). Smoking and vitamin C levels in humans. American Journal Clinical Nutritional, 21, 1259-1267. https://doi.org/10.1093/ajcn/21.11.1259

Rodriguez-Amaya, D. B. (1999). A Guide to Carotenoid Analysis in Foods. Washington: ILSI Pres. p. 63. Retrieved from http://beauty-review.nl/wp-content/uploads/2014/11/A-guide-to-carotenoid-analysis-infoods.pdf

Sarni-Manchado, P., \& Cheynier, V. (2006). Les polyphénols en agroalimentaire. Editions TEC \& DOC-Lavoisier, Paris. p. 147.

Sarr, S. O., Fall, A. D., Gueye, R., Diop, A., Sene, B., Diatta, K., NDiaye, B., \& Diop, Y. M. (2015). Evaluation de l'activité antioxydante des extraits des feuilles d'Aphania senegalensis (Sapindaceae) et de Saba senegalensis (Apocynaceae). International Journal Biology Chemist Scientific, 9(6), 2676-2684. http://dx.doi.org/10.4314/ijbcs.v9i6.13

Sarr, M. G., Ndiaye, N. D., Ayessou, N. C., Faye, P. G., Cisse, M., Sakho, M., \& Diop, C. M. (2018). Saba senegalensis: Key Features and Uses. Food and Nutrition Sciences, 9, 1099-1111. https://doi.org/10.4236/fns.2018.99080

Scalbert, A., Monties, B., \& Janin, G. (1989). Tannins in wood: comparison of different estimation methods. Journal of Agricultural and Food Chemistry, 37(5), 1324-1329. https://doi.org/10.1021/jf00089a026

Tee, E. S. (1992). Carotenoids and retinoids in human nutrition. Critical Review in Food Science and Nutrition, 31, 63-103. https://doi.org/10.1080/10408399209527563

Traoré, S., Assemand, E., Digbeu, D. Y., Kouadio, L. A., \& Brou, K. (2018). Combined Effects of Fermentation, Germination and Cooking Processes on the Nutritional Profile of Cowpea (Vigna unguiculata L) Grown in Côte d'Ivoire. Journal of Food Security, 6(4), 133-140. https://doi.org/10.12691/jfs-6-4-1

Traoré, S., Loukou, A. L., Agbo, A. E., Zah, M. C., Diabagaté, H. M. F., Camara, F., \& Brou, K. (2020). Influence of Morphological Variability on Nutritional and Technological Characteristics of Flours from Cowpea (Vigna unguiculata L., 1843) Grown in Côte d'Ivoire. American Journal of Food Science and Technology, 8(5), 176-184. https://doi.org/10.12691/ajfst-8-5-2

Vondruskova, H., Slamova, R., Trckova, M., Zraly, Z., \& Pavlik I. (2010). Alternatives to antibiotic growth promoters in prevention of diarrhoea in weaned piglets: a review. Veterinary Medicina, 55(5), 199-224. https://doi.org/10.17221/2998-VETMED

Weiguang, Y., Joan, F., \& Casimir, C. A. (2005). Study of anticancer activities of muscadine grape phenolics in vitro. Journal of Agricultural Food Chemical, 53(22), 8804-8812. https://doi.org/10.1021/jf0515328

Whitney, E., \& Rolfes, S. (2005). Understanding Nutrition (10th ed.). Thompson Wadsworth Publishing Company. p. 6.

Yoshikawa, T., Toyokuni, S., Yamamoto, Y., \& Naito, Y. (2000). Free Radicals in Chemistry Biology and Medicine. OICA International, London.

\section{Copyrights}

Copyright for this article is retained by the author(s), with first publication rights granted to the journal.

This is an open-access article distributed under the terms and conditions of the Creative Commons Attribution license (http://creativecommons.org/licenses/by/4.0/). 